\title{
LA REPRESENTACIÓN DEL TRABAJO FEMENINO EN LA MAR EN EL IMAGINARIO VISUAL ASTURIANO CONTEMPORÁNEO
}

\section{THE REPRESENTATION OF FEMALE WORK AT SEA IN THE CONTEMPORARY ASTURIAN VISUAL IMAGINARY}

\author{
Laura Mier Valerón \\ UNIR
}

\section{RESUMEN}

Con este artículo se pretende llevar a cabo una lectura comparada entre los trabajos femeninos asociados al mar, desempeñados por distintas generaciones de mujeres y de los que se tiene constancia a través de diversas fuentes, y su representación artística en el imaginario visual asturiano contemporáneo. En este sentido, se ha analizado un corpus de imágenes que, desde el siglo XIX hasta nuestros días, recogen estas labores, atendiendo no sólo a las voluntades de la mentalidad artística, sino también a la evolución socioeconómica de aquellas en nuestra región. A tal efecto, las imágenes estudiadas proceden de disciplinas como la pintura, de la cual hemos conservado una buena cantidad de ejemplos, seguida de la fotografía o de la imagen publicitaria.

Palabras clave: Trabajo femenino, mujeres del mar, pescadoras, litoral asturiano, representación visual

\section{ABSTRACT}

The aim of this paper is to tackle a comparative analysis of women in seaworks, well-depicted by sources, through the artistic approaching of contemporary Asturian imaginary. To the point, a corpus of images, that goes from the 19th century to the present, has been gathered to detect what intentions and purposes are connected to the artistic display. Not only attending to the will of the artistic mentality, but also to the socioeconomic evolution of these seaworks, these images involved varied information. The studied artworks come from disciplines such as painting, photography or advertising images.

Keywords: Female work, women of the sea, fishwomen, Asturian littoral, visual representation 


\section{APROXIMACIÓN A LAS REPRESENTACIONES: OFICIOS, COSTUMBRISMO Y GALANTEO}

A modo de introducción, trataremos de perfilar aquellos rasgos y lugares comunes que nos ayudarán a conectar las imágenes artísticas de nuestro interés y la realidad que representan. Como es bien sabido, las comunidades marítimas, aquellas que basan su actividad económica en las labores pesqueras, se rigen por un modelo organizativo que obedece al sistema sexogénero y que, a su vez, se vincula a otros patrones sociales expresados mediante binomios, como espacio público-espacio privado y mar-tierra. Al respecto, mientras que el espacio público se relaciona con el mar, lo masculino y lo productivo, lo femenino suele asociarse al espacio doméstico, la tierra y lo reproductivo o, en su defecto, a aquella esfera pública que, estrechamente hibridada en lo doméstico y privado, es escenario de labores complementarias para la economía familiar (Martínez García, 2017).

Al respecto, las obras analizadas han contribuido a la construcción de un imaginario que, casi como un continuo, responde a una distribución de la mujer entre el desempeño de las labores económicas y la encarnación de personajes de naturaleza socioafectiva. Para el contexto económico, nos encontramos con una serie de escenas que insisten en la organización de la economía familiar y en la recolección, distribución y venta de la pesca. Para el contexto socio-afectivo, se aprecian dos situaciones distintas que quedan ejemplificadas, por un lado, en la representación de toda una arquetípica galería de viudas, esposas e hijas de marineros y, por otro, en aquellas escenas de corte amoroso en las que las mujeres desempeñan un rol activo.

Sin embargo, en buena medida la representación masculina difiere de la femenina, ya que la presencia del componente emotivo queda en la primera reducida a las escenas de naufragios. Del mismo modo, las alusiones al estado civil o a la condición de parentesco, así como la expresión de dichas emociones, se reducen sensiblemente en la construcción de este imaginario del hombre (Mier Valerón, 2017).

No obstante, se puede decir que en la traslación de los trabajos costeros se advierte con claridad la realidad social, gracias a la expresión de la organización laboral y el desarrollo de las tareas. A tal efecto, es clara la discriminación por sexos de estos trabajos, pero también las transformaciones que experimentan los propios modos de expresión de las labores. Así, de forma reiterada, nos encontramos con imágenes que fijan la representación femenina en los trabajos de venta y distribución del pescado, quedando las labores de navegación y pesca a cargo de las figuras masculinas.

Dicho esto, no es menos cierto que casi todos los trabajos masculinos cuentan con escenas pictóricas, frente a ciertas ocupaciones femeninas, en muchas ocasiones, sin obras que las reflejen o con poca resonancia artística. En este sentido, conocemos la actividad de mujeres dedicadas a la industria de la transformación, como las trabajadoras del sector conservero, o aquellas otras que, con una voluntad empresarial, establecieron asociaciones de carácter cooperativo, como las de la comuña de Luanco ${ }^{1}$, todas ellas escasamente representadas².

Del mismo modo, hay oficios que han sido trasladados a la imagen plástica, pero en menor medida de lo que cabría esperar si tenemos en cuenta el calado de los mismos. Tal es el caso de las mujeres rederas, de quienes disponemos imágenes como Cosiendo redes (s.f.) de Luis Menéndez Pidal o Marineros en el puerto (ca. 1943) de Andrés Vidau, donde un pescador instruye a una niña en la reparación de las redes. Aunque sabemos que los propios pescadores arreglaban su instrumental, era frecuente encontrar mujeres rederas tejiendo y reparando, una actividad también relacionada con el predominio de mano de obra femenina en las fábricas de conservas. Uso tras uso, estas mallas tenían que ser arregladas y cosidas de nuevo, siendo esta última labor conocida con el nombre de adobado (Machicado Compañy, 1988) ${ }^{3}$.

1 Con este nombre se conoció a un grupo de mujeres cooperativamente asociadas en la villa de Luanco. Comerciaban con el pescado fresco y con las piezas del común, las cuales compraban a los patrones de las embarcaciones al entrar al puerto. Este pescado era revendido más tarde, siendo el beneficio obtenido repartido de forma equitativa entre todas (Fandos Rodríguez, 2000 y 2006). Véanse también noticias como https://www.Ine.es/aviles/2014/07/13/tres-decadas-comuna-19997328.html [Última consulta: 13-IV-2021, 15:48].

2 Se conservan fotografías de mujeres que participaron en sectores tradicionalmente masculinos, como el armador. Al caso, véase a La Papiega, empresaria armadora del puerto de Luanco, que fue fotografiada por E. Bosquets (Fandos Rodríguez, 2000).

3 Ya sean fijas, de deriva, de cerco o de arrastre, en función de su posicionamiento sobre el agua, estas redes son mallas provistas de una armazón exterior que se desarrolla entre relingas o cabos (Rodríguez Rodríguez, 2006b: 182-183). 
Retomando lo expuesto para la representación de los trabajos, se tiene constancia de que esta traza del perfil laboral femenino, tendente a su circunscripción doméstica, no es exclusiva de la imagen artística ni se reduce a nuestro ámbito geográfico (Broullón Acuña, 2011; Macías Muñoz, 2016). Igualmente, algunas de estas ocupaciones se recogen parcialmente en las fuentes oficiales, bien porque la metodología empleada en el sistema de registro las excluya, bien porque algunas de las actividades, como las auxiliares a la pesca (redería, venta, transporte y recogida de algas) ni siquiera se computan (Muñoz Abeledo, 2012)4.

Asimismo, la dureza implícita en este modo de vida suele simplificarse a través del proceso de idealización plástica. Sabemos que las mujeres marineras desempeñaban los trabajos de la casa y del cuidado familiar, así como aquellos relacionados con la economía doméstica. Además, estas figuras se responsabilizaban de los quehaceres del cultivo de la tierra y del autoabastecimiento alimentario tras la partida del hombre a la mar. A este cúmulo de cargas se le sumaban la incertidumbre y la pesadez de las largas esperas, tanto para faenar como para recibir los ingresos de la pesca, los cuales a veces no llegaban por las malas jornadas o por los temidos naufragios. Entonces, con la viudedad, aumentaba la gravosa carga de trabajos y responsabilidades, así como se reducían los ingresos y las manos disponibles para trabajar. En este sentido, conocemos la inseguridad generada por la irregularidad y la fluctuación de estos pagos a lo largo del año, más abundantes cuando se daban buenas costeras y escasos en épocas de temporales (Fandos Rodríguez, 2006).

Sin embargo, en las imágenes rastreadas se aprecian una serie de características que nos hablan de la voluntad artística. Por ejemplificar esta cuestión, la iconografía de los trabajos de labranza suele reflejar al hombre y a la mujer trabajando al unísono. De este modo, se

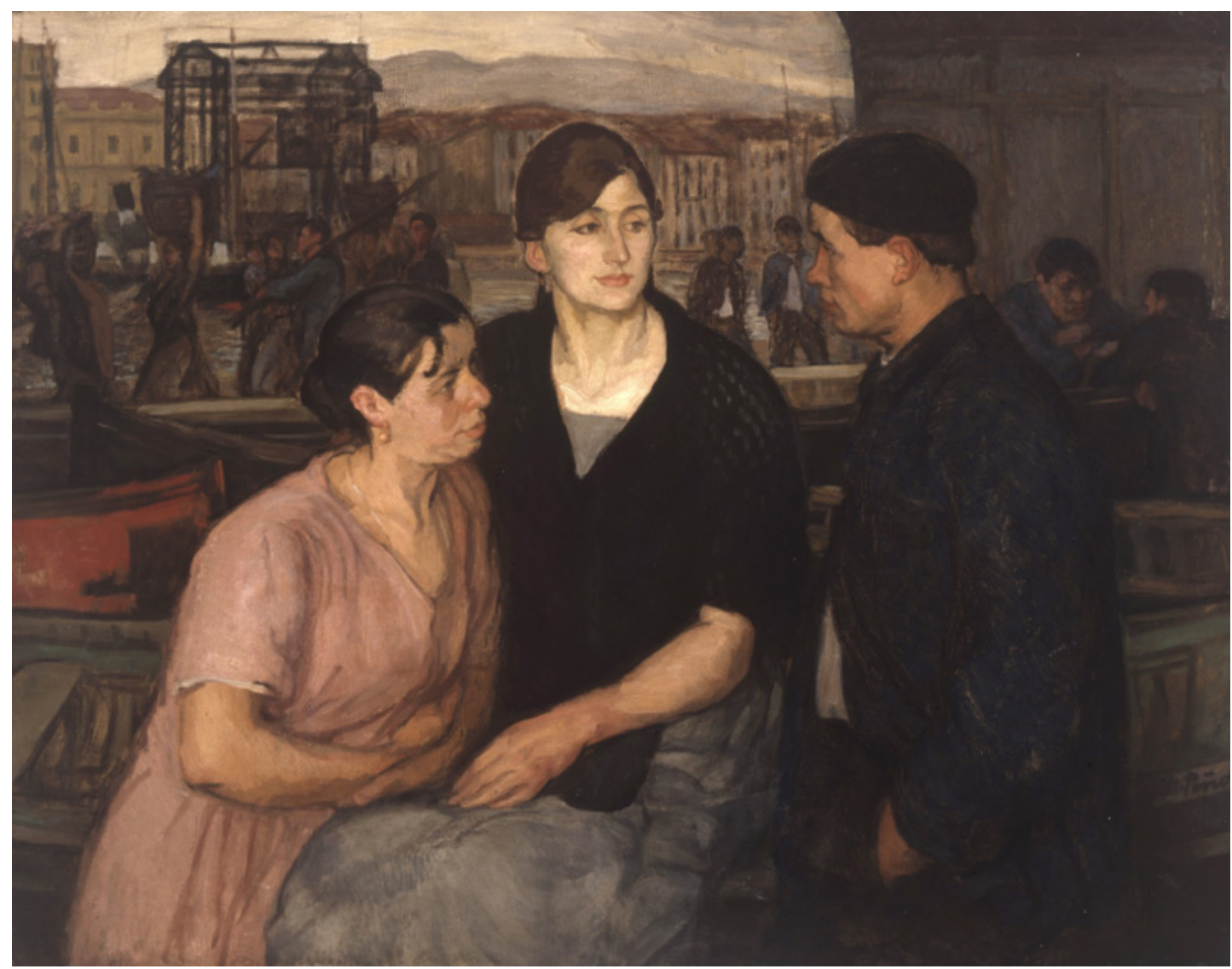

Figura 1. La hija del patrón (1924) de Nicanor Piñole. Colección Museo Casa Natal de Jovellanos (Gijón).

4 En este sentido, existen estudios que recogen la ocultación de estos trabajos en fuentes como los censos poblacionales. Véase Muñoz Abeledo, 2012. En términos generales, para esta cuestión consúltese Pérez Fuentes, P. (1995) El trabajo de las mujeres en la España de los siglos XIX y XX. Consideraciones metodológicas, en Arenal. Revista de historia de las mujeres, 2,2: 219-245; Pérez Fuentes, P. (2003). Ganadores de pan y amas de casa: los límites del modelo de male breadwinner family (Vizcaya, 1900-1965), en ¿Privilegios o eficiencia?. Hombres y mujeres en los mercados de trabajo. Alicante: Universidad de Alicante: 217-241. Con otra voluntad y para estudios sobre composición familiar y laboral en zonas marítimas asturianas: Suárez Álvarez, P. (2013). Familia y sociedad en un concejo marítimo del noroeste peninsular: el municipio asturiano de Carreño en 1753. En Estudios Humanísticos. Historia, 12 : $397-416$. 
ha prescindido frecuentemente de la representación femenina en solitario, cuando sabemos que esta acción era habitual. En otras ocasiones, el trabajo de la tierra y del ganado queda enmarcado en una escena de galanteo, en donde se presentan los motivos elegidos fusionando labor y cortejo. Llendando (s.f.) de Ventura Álvarez Sala, una pintura que aúna espacio litoral, referencias portuarias, labores de pastoreo y escena de cortejo, nos muestra una pareja de mozos allendando el ganado en medio de un ambiente de goce y despreocupación ${ }^{5}$.

Siguiendo esta línea, otras obras traducen los espacios marineros mediante un registro costumbrista que busca atraer la atención del espectador con imágenes de la cotidianeidad. No obstante, estas escenas también son reflejo de la realidad social que tenía lugar en las zonas de trasiego y, por tanto, de fricción entre hombres y mujeres. Ambientadas en el puerto o en la playa, suelen recoger escenas amorosas y familiares. Por un lado, identificamos el tema del cortejo, como En el puerto $(1890)^{6}$ de Juan Martínez Abades o en La hija del patrón (1924) de Nicanor Piñole. Por otro, encontramos otras imágenes que emplean estos paisajes como escenario para la retratística, véase Familia marinera (1867) de Dionisio Fierros.

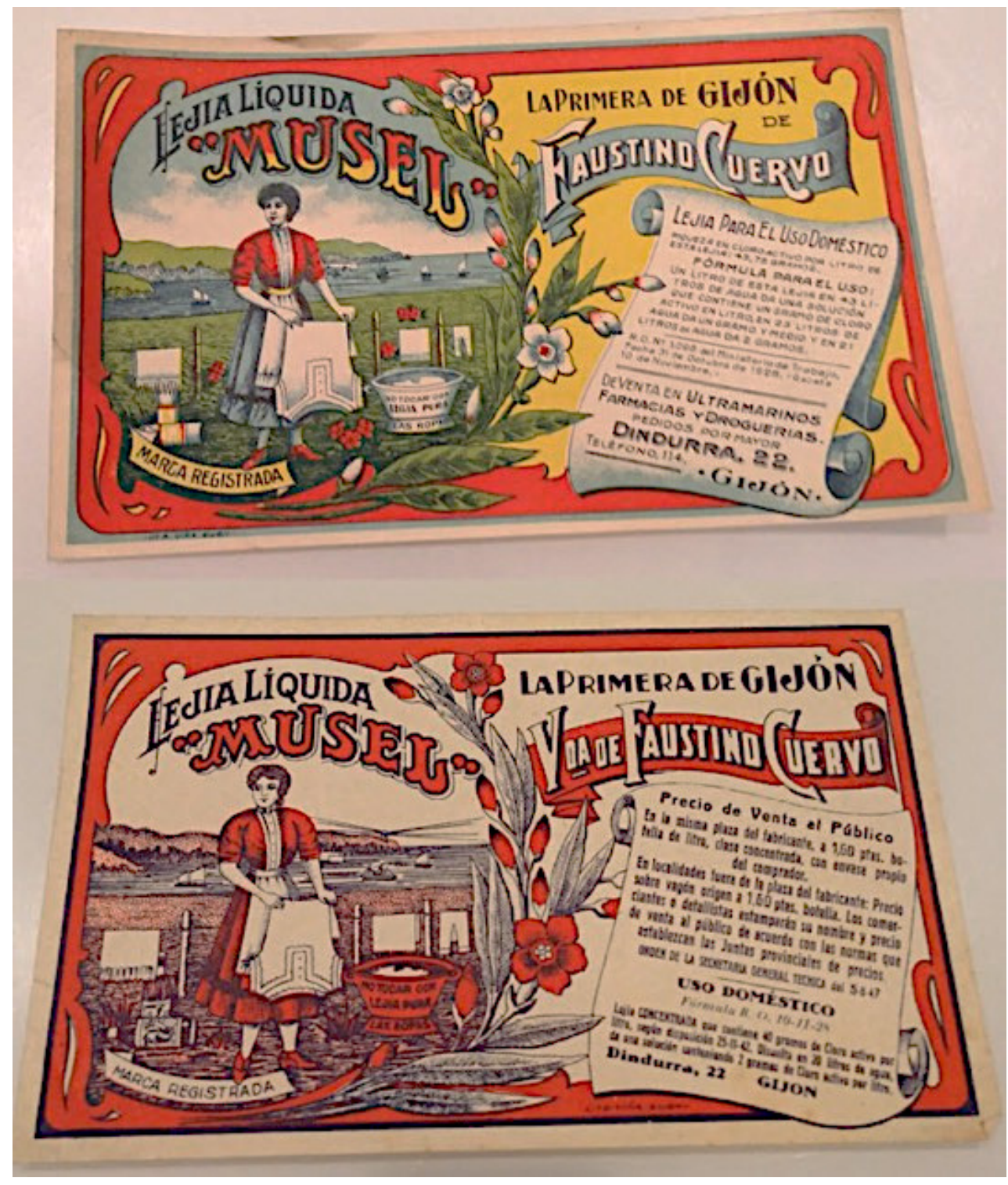

Figura 2. Etiquetas comerciales de "Lejía Musel” (ca. 1930). Colección del Museo del Pueblo de Asturias (Gijón).

5 Si bien la voz se transforma en función de la zona, se entiende por allendar, llendar o llindar el vigilar, cuidar, pastorear o apacentar el ganado. Véase https://mas.Ine.es/diccionario/buscador?q=allendar. [Última consulta: 12-IV-2021, 18:02].

6 La obra En el puerto (1890) fue conocida como Idilio de pescadores por el tema representado. No obstante, también nos interesa por la representación de algunas herramientas de trabajo, como el balde, recipiente oval realizado en madera y con asa de cuerda, que era utilizado por los marineros para llevar la comida cuando los víveres corrían a cuenta de cada tripulante. Además, este recipiente tenía una doble función, puesto que a la vuelta se empleaba para traer la parte del pescado correspondiente (Díaz Quirós, 2006: 142-143). 
De igual modo, otras imágenes se hacen eco de las labores domésticas, entendiendo éstas con un sentido general, para ambientarlas en parajes litorales. En ocasiones, estas imágenes han sido creadas en el marco de la tipología publicitaria, siendo estas iconografías domésticas explotadas con una voluntad económica.

\section{CARACTERÍSTICAS GENERALES DE LAS REPRESENTACIONES ANALIZADAS}

En la representación de estos trabajos, la pintura es una de las disciplinas artísticas más destacadas como fuente de estudio por la gran cantidad de ejemplos que nos ofrece, junto a la fotografía y otras, ya no tan abundantes, como el dibujo y el grabado. Generalmente, las imágenes fotográficas disponibles, ya respondan a un enfoque más bien artístico, más bien documental, suelen refrendar el contenido temático de las pinturas, si bien los modos de representación cambian en ocasiones. Sobre la autoría de estas obras, encontramos una nómina de artistas de gran relevancia y repercusión, como Ventura Álvarez Sala, Nicanor Piñole, Evaristo Valle o Mariano Moré, aunque algunos de ellos sobresalen como principales hacedores de la temática. En este sentido, Ventura Álvarez Sala y Nicanor Piñole nos han brindado un buen número de pinturas sobre las actividades y los oficios portuarios. Asimismo, la preeminencia de aquellas obras salidas del estudio de ciertos artistas condiciona otro rasgo, el cronológico, con una destacada presencia de obras que han sido creadas entre finales del siglo XIX y la década de 1970 (Mier Valerón, 2017).

Como ya se ha dicho, los trabajos representados se estructuran en base a la especialización por sexo-género, por lo que encontramos una serie de espacios laborales masculinos, otros propiamente femeninos y algunos de tipo mixto, en los que hombres y mujeres se entremezclan (aunque estos últimos tienen menor presencia que los anteriores). De este modo, los hombres fundamentalmente desempeñan roles ambientados en alta y baja mar (navegante o pescador) así como algunos otros anclados a tierra firme, pero relacionados con los anteriores (descargador o estibador) ${ }^{7}$.

Aunque las mujeres aparecen representadas como pescadoras, su iconografía se caracteriza por su naturaleza recolectora, contrapuesta al rol cazador masculino. De este modo, las pescadoras aparecen en la orilla del mar, a veces a pie de playa, otras entre los característicos roquedos, para recoger moluscos y algunos mariscos de pequeño tamaño. De igual forma, conservamos imágenes de la obtención de otro tipo de recurso de gran importancia, el del ocle. Esta alga marina, de color rojizo, se recogía y acumulaba en pilas o montones posteriormente sacados de los arenales en carretas movidas por animales de tiro. Muy valorada para las tareas agrícolas, era empleada como abono en las pequeñas parcelas de tierra familiares (Pérez de Castro, 1963).

En este sentido, contamos con obras como Cargando ocle (s.f.) de Francisco Esteve Botey, quien retrata la escena representada con verismo, así como Al ocle en Luanco (1998) de Valentín del Fresno, donde un grupo de mujeres recolecta este alga en la playa de La Ribera de Luanco, ayudándose de la típica horca (forcáu de fierru) para acumular estos algazos antes de ser cargados. Siguiendo lo expuesto, recurrimos de nuevo a la temática de la labranza, actividad con la que el ocle se relaciona estrechamente. En Arando la tierra (1910) de Ventura Álvarez Sala, una pareja acompaña al ganado, guiándolo en los movimientos necesarios para tirar de un pesado arado, tarea del ciclo agrario tras la cual se plantaban verduras, hortalizas y algún tubérculo necesitados de cierto abono. Sin embargo, las comunidades costeras no contaban con la cabaña ganadera necesaria para producir estiércol suficiente, situación que convertía esta alga en el fertilizante más accesible ${ }^{8}$.

7 Esta es una realidad común para el espacio atlántico, pero también para el ámbito mediterráneo. A tal efecto, consúltese Calo Lourido, F. (1997). Peculiaridades de la sociedad marinera. En Galicia: Antropología. Coruña: Hércules de ediciones, vol. 26: 200231; VV.AA. (2017). Los Poblados Marítimos. Historias, lugares y escenas. València: Ajuntament de València.

8 De ahí la prisa de estas mujeres por bajar a recoger las primeras algas, a veces acompañadas del hombre y, frecuentemente, de los niños. La dinámica descrita se mantiene hasta la década de 1950, momento en el cual el proceso de recogida de algas sufre importantes cambios. El ocle no sólo era empleado como abono o fertilizante. También le eran atribuidas virtudes curativas, como se recoge en: Bellmunt, O. y Canella, F. (1990). Asturias: su historia y monumentos, bellezas y recuerdos, costumbres y tradiciones, el bable, asturianos ilustres, agricultura e industria y estadística. Gijón: Fototip. y Tip. O. Bellmut. 
Como hemos apuntado, otro trabajo femenino fue el de la recepción, venta y distribución de la pesca, repercutiendo en la creación de otra de las principales iconografías, la de la vendedora de pescado -que cobra especial fuerza en el caso de las sardineras-. Además, las mujeres fueron asiduas a las subastas que tenían lugar en las diferentes rulas regionales, sobre todo en época de costeras (como la del bonito o el besugo), ocupando uno de los espacios mixtos más destacados de la imagen artística costera. Atentas a la inspección del género, solían acudir en compañía de los más pequeños de la casa. Del mismo modo, estas mujeres trascienden el rol de vendedoras y consumidoras, ejerciendo a su vez de ponedoras, trabajadoras conocidas por clasificar y preparar el pescado que iba a ser subastado.

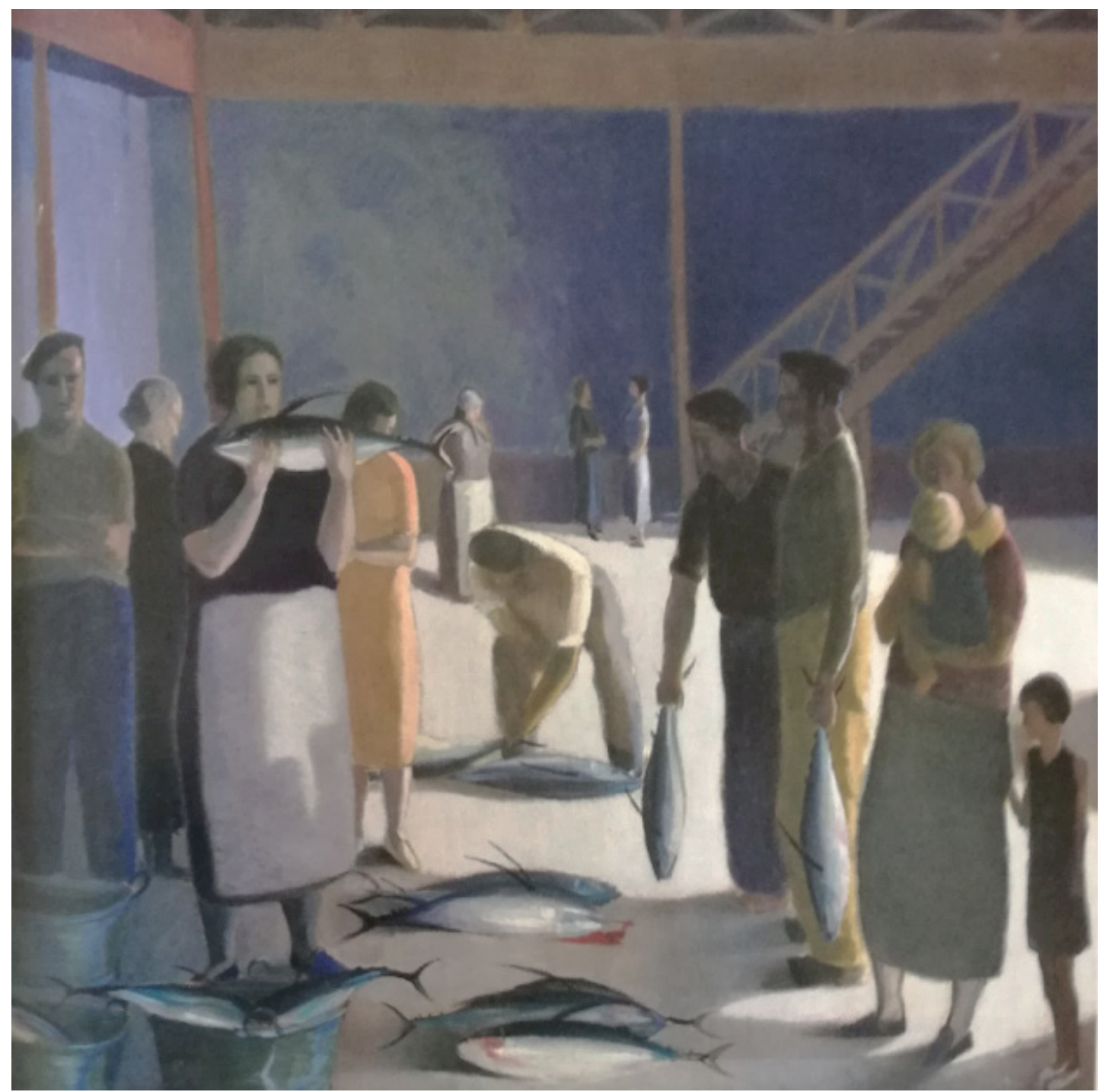

Figura 3. En la rula (1935-1936) de Luis Bayón.

\section{TRABAJOS Y ESPACIOS FEMENINOS: SU TRASLACIÓN A LA IMAGEN ARTÍSTICA}

Tal y cómo se comentaba, no todos los trabajos que corrían a cargo de las mujeres han quedado recogidos de igual forma en aquellas imágenes de nuestro interés. Como también ocurría con las iconografías del trabajo masculino, aunque de un modo sensiblemente distinto, las tareas femeninas quedaron sujetas a un proceso de cristalización iconográfica, pudiendo advertirse tres estereotipos esenciales en la presentación de la mujer marinera: la mariscadora, la porteadora, transportadora o distribuidora y la pescadera o vendedora. 


\subsection{EL TRABAJO DE LAS MARISCADORAS}

El radio de la pesca femenina quedaba arraigado en el límite entre la tierra y la mar, por lo que estas imágenes se desarrollan en el marco de los arenales, reflejando la captura y recolección de especies de pequeño tamaño, sobre todo crustáceos y moluscos, ubicados en los típicos pedreros. Esta recolección o marisqueo constituía una fuente de ingresos muy apreciada, especialmente para las mujeres de menores recursos. A tal efecto, es muy habitual la presencia de las viudas en estas escenas, característicamente ataviadas de negro, quienes hicieron de esta faena una actividad fundamental.

Ventura Álvarez Sala nos proporciona una de las obras más completas, desde el prisma de la narración laboral, en Pescadoras de marisco (1912). Unas pescadoras son retratadas en plena faena y en compañía de los instrumentos necesarios para marisquear a pie, como las bistronzas, bistoncias o covadoiras, unas estrechas y afiladas palas de acero que, con un largo mango de madera, eran empleadas para despegar los moluscos de la roca, los cuales iban a caer al truel o pequeña red de forma cónica. También se observan las típicas cestas o paxos, que servían para guardar lo recolectado y transportarlo fácilmente, así como para ayudar a cargar el utillaje. En la imagen se advierten distintas tipologías cesteras y herramientas para las capturas, como la vara alargada que se utiliza para coger el pulpo, o los distintos portes en los que se llevan oricios y andaricas.

Las lámparas, las ostras y los bígaros habían de ser arrancados de las rocas del pedrero, los percebes despegados de los riscos de los acantilados y los bivalvos, como las almejas, las navajas y los berberechos, rebuscados de entre las arenas y los lodos, en donde había que excavar para retirar la capa superficial de la arena9. Como en la obra, las mujeres iban vestidas con una saya larga, hasta los tobillos, sobre la que se colocaba un holgado mandil. También portaban pañuelo, generalmente sobre los hombros o atado en torno al cuello, si bien la viuda lo lleva sobre la cabeza ${ }^{10}$, siendo, a su vez, la única que calza madreñas (frente a las alpargatas que llevan el resto de las mozas) ${ }^{11}$.

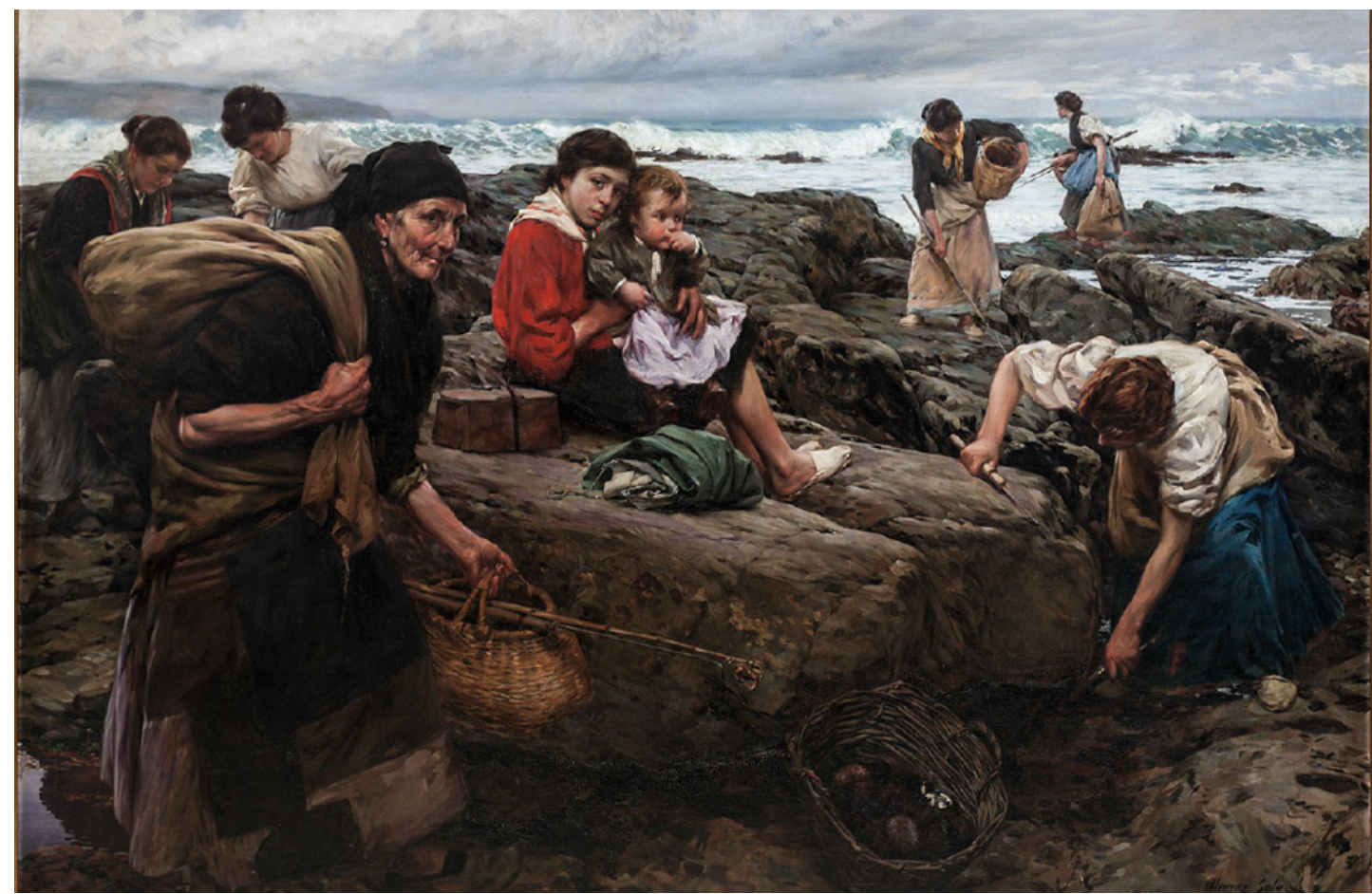

Figura 4. Pescadoras de marisco (1912) de Ventura Álvarez Sala. Colección del Museo Casa Natal de Jovellanos (Gijón).

9 También conservamos ejemplos fotográficos que nos muestran la recolección de otros mariscos, como en Pescadoras de oricios (ca. 1928) de Constantino Suárez. En esta fotografía se observa a un grupo de mujeres, ataviadas de forma parecida, trabajando en la recolecta. La fotografía se reproduce en Norte, n. 24, Madrid, 1931.

10 Fandos recoge que la costumbre de llevar la cabeza cubierta se mantuvo hasta bien entrado el siglo XX, como parte de esta vestimenta. Para justificar la antigüedad de este hábito, la autora cita las palabras de Carlos González Posada (1792), quien dice que las de Candás fueron las primeras mujeres en usar el pañuelo atado a cabeza (“como las griegas”), de donde lo tomaron las demás. Este tocado se denomina "pañuelo a la candasina" (Fandos Rodríguez, 2006: 280).

11 Por múltiples razones, es la viuda uno de los personajes más llamativos de la composición. El eco del que gozó la obra y la trascendencia del personaje hicieron que fuera empleado como reclamo para el logo de una marca de anís (etiquetas comerciales de Anís La Muyerina (ca. 1992), catalogadas en el Museo del Pueblo de Asturias). 
A la faena había que ir lo más cómoda posible, por lo que estas mujeres dejaban sus ropas de diario para vestir la ropa de bayeta, una indumentaria más confortable que les permitía mayor libertad de movimientos. Una vestimenta de esta naturaleza era fundamental para el desempeño de estos trabajos, tanto por los movimientos realizados como por su ejecución intensiva durante las horas de bajamar. Este tiempo era aprovechado de continuo, hasta que la marea comenzaba a subir, habiendo entonces de retirarse del pedrero o acantilado.

También conservamos otras obras que plasman los momentos previos a las recogidas, como se aprecia en Mariscadoras (s.f.) de Mariano Moré, una valiosa imagen que traduce el momento más tedioso de estas jornadas. Entonces, las mariscadoras se situaban en torno al pedrero o acantilado, preparadas con bastante antelación, aguardando a que bajase la marea y que se pudiese faenar. Aunque en Pescadoras de Marisco ya se percibía esa miscelánea entre lo público y lo privado, lo laboral y lo doméstico, y el trabajo pesquero y la crianza, es en Las Mariscadoras donde resulta más evidente. Aquí toda la unidad familiar se traslada a las inmediaciones de la faena, figurando niños y niñas de distintas edades, quienes también habrán de arrimar el hombro bajo la supervisión y el cuidado de sus abuelas, madres y hermanas. Asimismo, se distingue una galería de retratos, en los que la caracterización femenina termina por perfilarse entre los rasgos y la vestimenta de las representadas, la cual nos alerta de sus edades y estados civiles.

Sin embargo, el paso del tiempo nos muestra cómo los antiguos usos y costumbres van cambiando, dando lugar a otros códigos en el vestir. En A Llámparas (2006) de Favila, las mujeres van ataviadas de otro modo, así como la edad media de las trabajadoras es más elevada y homogénea que en los ejemplos anteriores. Esta cuestión responde a la drástica reducción del número de mujeres dedicadas a las labores de marisqueo, incluso en aquellas zonas más prolijas en este tipo de recursos pesqueros y en donde estas actividades habían arraigado con más fuerza.

\subsection{LAS LABORES DE RECEPCIÓN, DISTRIBUCIÓN Y LA VENTA DE LAS CAPTURAS}

Como hemos podido ver, el marisqueo a pie ha quedado históricamente desempeñado por mujeres, ya fuera en la realidad cotidiana o en su representación. Para las labores de transporte, distribución y venta también encontramos fundamentalmente mujeres, siendo lógico que, de entre los oficios femeninos, estos cuenten con un mayor volumen de obra y afecten a la popularización de la iconografía de la vendedora de pescado.

En todas estas imágenes aparece el típico cesto vegetal o paxo, herramienta fundamental de estas trabajadoras. Aunque en la actualidad paxo y cesto se emplean como sinónimos, existen algunos matices entre los distintos modelos y tipologías, si bien, a pesar de las distintas clasificaciones, estos útiles pueden ser agrupados de forma más sencilla en dos bloques. Por una parte, está el grupo de los paxos o canastos de mayor tamaño, que cuentan con las asas más pequeñas y que, en su defecto, pueden llegar a prescindir de ellas (comúnmente empleados por lo campesinos en las labores agrícolas). Por otra, se encuentra el grupo de paxes o cestes, empleados tanto en tareas del campo como de la mar, que siempre cuenta con asas. En el caso de los trabajos marineros, estas cestas se pueden conocer bajo el nombre de paxa o paxica de mar, disponiendo a su vez de algunos matices particulares (Rodríguez Rodríguez, 2006c).

A grandes rasgos, se pueden extraer algunas conclusiones de la literatura sobre estas cestas, girando la primera en torno a la humanización de estos objetos, con la consiguiente dotación de un género. En este sentido, los paxos son masculinos y quedan fijados al marco rural y agrícola, siendo también los que poseen un mayor tamaño y los que son empleados en tareas que, por lo general, requieren portar un mayor volumen de mercancía. Por el contrario, las paxas y las paxicas son femeninas, las utilizan las mujeres, disponen de una capacidad menor y siempre cuentan con asas que se corresponden con las dimensiones de una mano.

Siguiendo el primer modelo de paxos, encontramos diversas representaciones de mujeres cargándolos sobre la cabeza, especialmente en escenarios portuarios. Probablemente abunden en estas localizaciones porque la orografía no tiene un perfil tan accidentado ni escarpado como en el pedrero, por lo que las paxicas de boca estrecha no se hacen tan necesarias. Ludi en el muelle (1928) de Nicanor Piñole nos muestra a varias mujeres llevando paxos de vara gruesa en 
las inmediaciones de la rula del puerto gijonés. Sin embargo, no es la única obra que perpetúa escenas de recepción y de transporte del pescado, ya que contamos con otras como Pescaderas (1926) de Alfredo Aguado y Pescadores de Lastres (1948) de Mariano Moré.

Alfredo Aguado pone su atención en un pequeño grupo de mujeres del puerto de Avilés, que cargan el pescado en las características paxas de blima (sin asas y pensadas para ser llevadas sobre la cabeza), ofreciéndonos una secuencia sobre la preparación y la carga de la paxa. Resulta interesante cómo la última de las mujeres aparece con el característico rodete o rodiella, un trapo blanco que se disponía entre la cabeza y la cesta para amortiguar las molestias ${ }^{12}$.

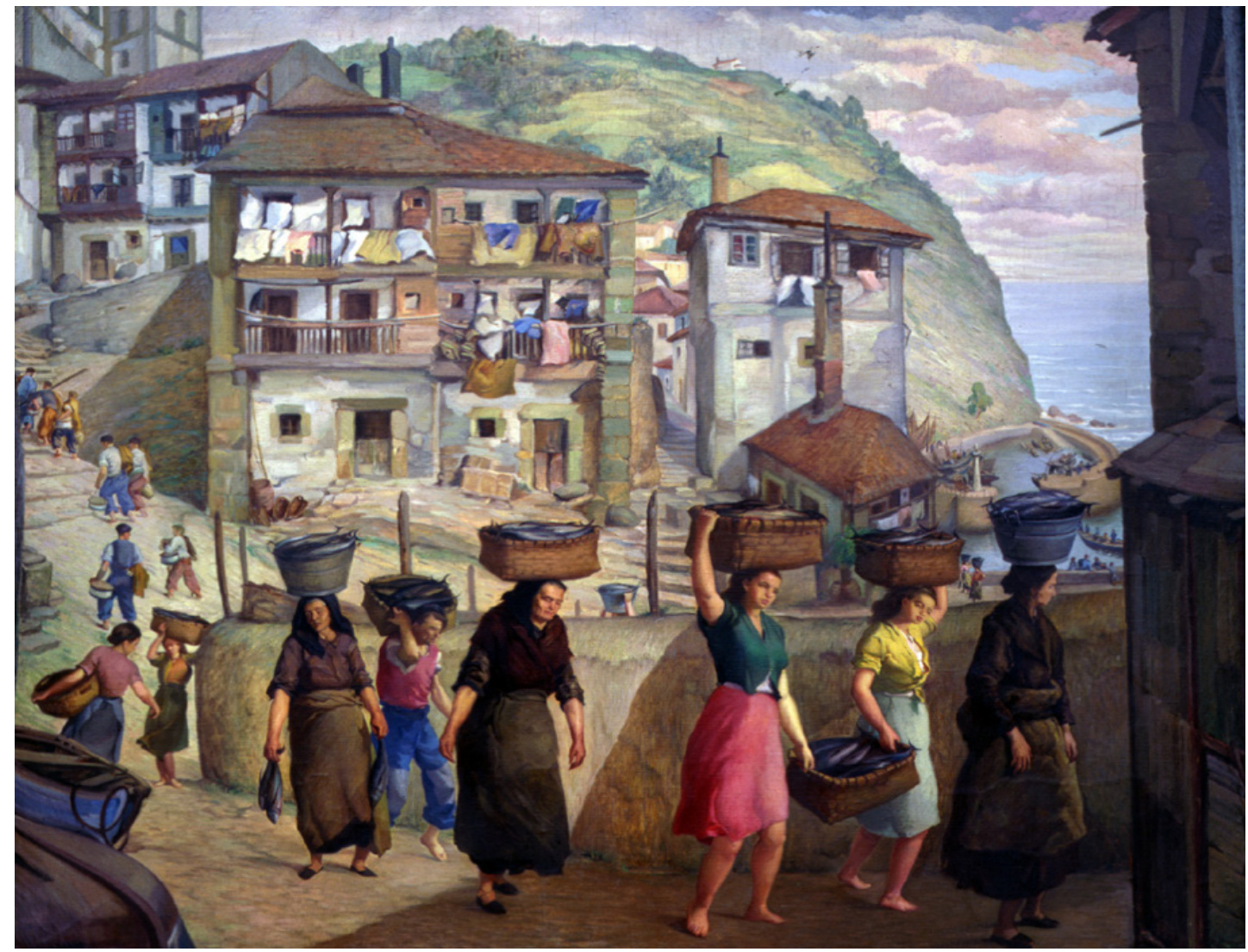

Figura 5. Pescadores de Lastres o puerto de Lastres (1948) de Mariano Moré. Colección Museo Nacional de Arte Reina Sofía (en depósito en el Museo Casa Natal Jovellanos de Gijón).

Sin embargo, Mariano Moré prefiere emplear una composición monumental, sin prestar tanta atención al utillaje y centrándose en la narrativa visual de la cadena femenina desplegada sobre el escenario. Si la obra anterior nos permitía comprobar cómo las mujeres cargaban el pescado, Puerto de Lastres de Moré nos muestra el recorrido, con una voluntad casi procesional, que estas mujeres realizaban desde el puerto local hasta la rula de la villa de Lastres. Saliendo de la dársena local para subir las farragosas cuestas, aparecen cargadas con goxes vegetales ${ }^{13}$, rectangulares y sin asas, sobre sus cabezas. También recoge Moré los típicos barreñones de zinc, que aquí son llevados por las viudas.

Igualmente, hay imágenes de la espera femenina a la llegada de las embarcaciones con el pescado, como De arribada (s.f.) de Jesús Gallego y algunas fotografías que recogen el momento de su recepción, como Llegada de la pesca y momento en el que pasa al público en el Mercado de San Lorenzo (ca. 1925) de J.M. Mendoza y Ussía. Es la fotografía de Ussía y Mendoza la que nos ofrece más información, puesto que, una vez recibido el pescado, las ponedoras ya han colocado la mercancía, no sin cierta gracia, para persuadir al comprador.

12 Véase el uso de la voz rodiella (García Arias, 2007: 357).

13 Acepciones, usos y costumbres sujetos a la voz goxa: "Cesta, banasta". "Banasta, cesta de verdiasques, sin asa por encima, aunque puede tener dos asas laterales". "Cesto de varas". "Cesto de banielles, redondo, de poco fondo y sin asas, usado en la plaza para la fruta”. Véase en DGLA, http://mas.Ine.es/diccionario/palabra/42661 [Última consulta: 13-IV-2021, 18:57]. Además, la mujer aparece vinculada al empleo y a la fabricación de estas cestas (Junquera Huergo, J., 1991: 103). 


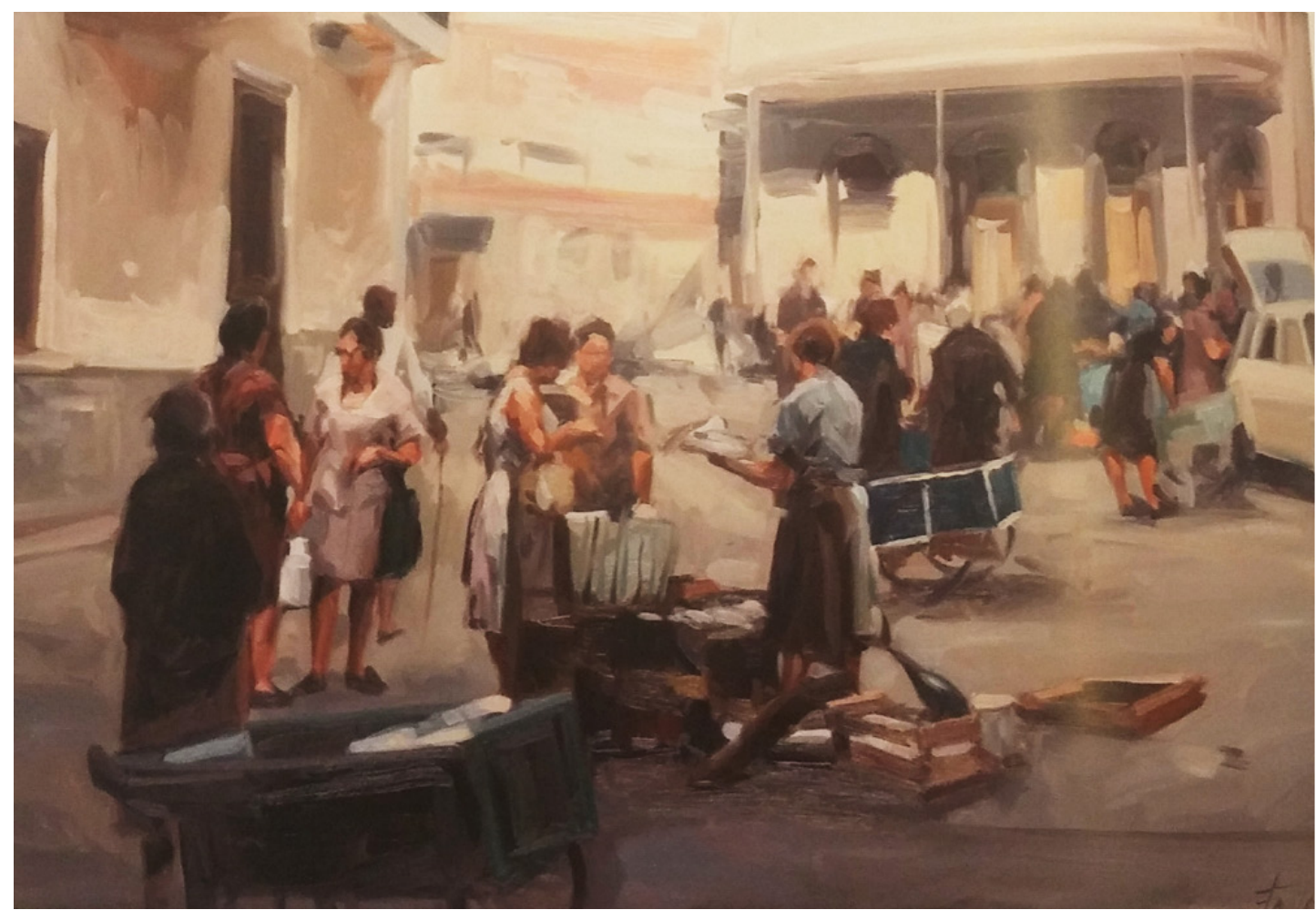

Figura 6. Pescadoras de Cudillero (1997) de Favila. Colección particular.

Sin embargo, una de las obras que mejor ejemplifica este momento es Pescaderas en Cudillero (1997) de Favila. Si bien el autor parece interesarse por un instante ya avanzado en la jornada de venta, todavía se perciben la algarabía y el ruido propios del medio de estas vendedoras. Conocidas como sardineras, vendedoras pol mundo, baldonas, muyeres de la paxa, del pescado o voceadoras pol mundo (Fandos, 2006: 282), estos nombres dan cuenta del papel voceador de estas mujeres, que pregonaban las virtudes del género que vendían, no sólo en el mercado, sino también durante el trayecto que realizaban entre el punto de recepción y el puesto de venta.

Del mismo modo, sabemos que el volumen de trabajo de estas mujeres se vio favorecido a partir de la mitad del siglo XIX, cuando las ciudades y villas costeras asturianas comenzaron a experimentar los beneficios del fenómeno del veraneo y de la afluencia de las gentes del interior. A tal efecto, se disparó el consumo de pescado local al ser de mejor calidad y más barato que el disponible en sus lugares de origen. Al igual, el desarrollo de la industria conservera provocó un incremento de las capturas, proliferando la presencia de estas mujeres en las inmediaciones portuarias, así como en aquellos escenarios objeto de representación artística, consolidándose la iconografía de la pescadera hasta dar lugar a un género propio (Mier Valerón, 2017).

Al respecto, tenemos ejemplos como Sardinera (ca. 1895) de Félix González-Nuevo, paradigma de lo que habría de ser su retrato. Esta mujer porta una paxa de blima circular sobre la cabeza, con sardinas (que también podían ser xardas), y posa descalza, vestida con una saya larga, con mandil por encima y con pañuelo atado al cuello. Aunque no es la primera vez que vemos estos atributos en su representación, destaca la individualización y la monumentalidad de la figura, así como el tipismo de la imagen, probablemente ambientada en el paisaje de la desembocadura del Nalón (Fandos Rodríguez, 2006) ${ }^{14}$. Estos rasgos se repiten en otras obras como Gentes de Mar (1968) de Marola, donde los personajes femeninos aparecen de nuevo con las características paxas.

14 Las mujeres de esta zona, que vendían el pescado en el puerto de San Esteban de Pravia, también se dedicaban a la recogida de carbón en la desembocadura de la ría. Para su obtención, raspaban la superficie de la arena, rescatando los restos carboníferos depositados en ella. Con ellos, iban formando pequeños montones de cisgo, depositándolos por el arenal para después llevarlos a casa a secar y a ser vendidos. Una parte se la quedaban para emplearlo como combustible en sus cocinas de carbón. 


\subsection{LOS TRABAJOS DE LIMPIEZA Y DESPIECE}

Aunque menos frecuentes, podemos encontrar obras que nos enseñan los trabajos de limpieza y despiece del pescado, así como el procesado de las materias primas. Mujeres descabezando pescado (1968) de Magín Berenguer refleja la preparación del pescado para su posterior exposición y venta, acompañándose sus protagonistas de los útiles típicos. Continuando con el procesado, llegamos a una de las pocas obras pictóricas que testimonia el desarrollo de una jornada de trabajo de las conserveras. La Cantabria (1895) traduce las labores de limpieza y manipulación que tenían lugar en el interior de estos locales, especialmente abundantes en Gijón a finales del siglo XIX. Entre los años 1890 y 1900, el distrito marítimo y el puerto de Gijón contaban con siete fábricas dedicadas a la producción de conservas enlatadas, así como veinte bodegas destinadas a la producción de salazones y escabeches, estando a la cabeza de la producción conservera asturiana (Ocampo Suárez, 1990).

No obstante, en esta ocasión conocemos qué fábrica se está representando: "La Cantabria" de Valentín Sendín Pedrós. También sabemos que este cántabro fue una figura clave en la renovación del sector astillero y armador local y que, a principios del siglo XX, contaba con una fábrica en el barrio de Cimadevilla (en la antigua calle de Santa Catalina), donde se preparaban y enlataban sardinas, besugos y bonitos, exportándose a otros puntos de España, Francia e Italia. La situación de este negocio era inmejorable al localizarse en el propio puerto gijonés, como ocurría con los negocios de los Alvargonzález, mientras que otras fábricas y bodegas, que habrían corrido peor suerte, disponían de una ubicación menos céntrica. También sabemos que este negocio llegó a contar con una plantilla de trabajadores de unos 100 hombres, casi todos contratados para la pesca y captura, y unas 30 mujeres $^{15}$ que trabajan en la fábrica limpiando, preparando y conservando el pescado (Rodríguez Rodríguez, 2006a: 70-71).

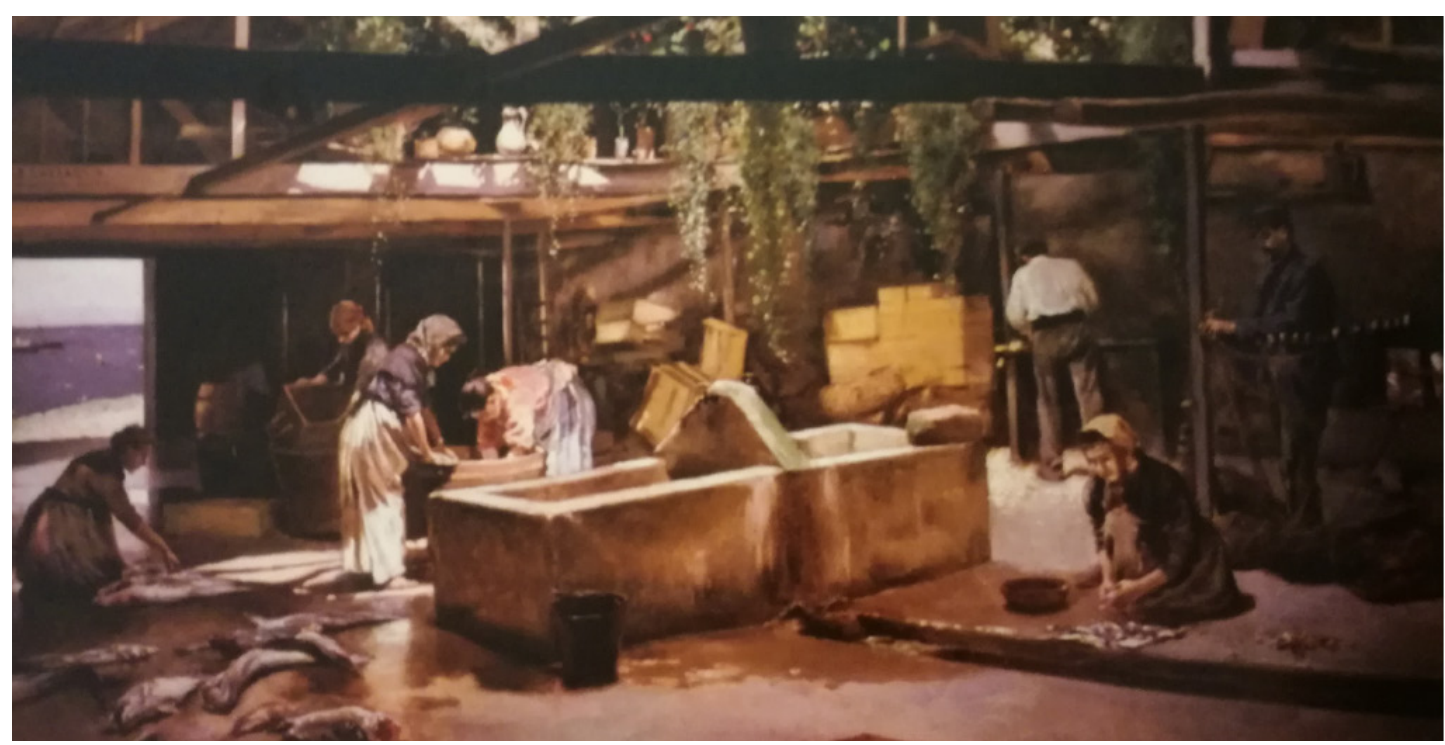

Figura 7. La Cantabria (1895) de Juan Martínez Abades.

En este sentido, la obra de Juan Martínez Abades ilustra la composición y dinámica laboral del negocio, mostrándonos cómo las mujeres descargan el pescado de las cajas, colocándolo en el suelo y limpiándolo cerca del lavadero, preparándolo para su despiece y posterior procesado.

\subsection{LA ICONOGRAFÍA DE LA PESCADERA: ENTRE LA IDEALIZACIÓN Y LO CARICATURESCO}

Encontramos interesantes escenas corales sobre estas mujeres en obras como Pescaderas (ca. 1949) de Evaristo Valle, una estampa colectiva en la que se caracteriza, de forma individualizada

15 Atendiendo a la localización geográfica y a la cronología consultadas, los porcentajes de contratación de mano de obra por sexos se transforman. A tal efecto, la mano de obra femenina se dispara a partir del primer cuarto del siglo XX. Para el año de 1933 se recogen en Luanco, una villa que contaba con industrias de gran calado, como la de Cabo Peñas, un total de 673 trabajadores en el sector. De éstos, 100 eran hombres (14,9\%) y 573 mujeres (85,1\%). Estos datos, extraídos de la Estadística de Pesca de 1933, aparecen recogidos por Muñoz Abeledo (Muñoz Abeledo, 2012: 62). 
y en la línea de lo caricaturesco, a sus protagonistas. Plasma Valle diversas mujeres dedicadas al oficio, de distintas edades y rasgos, desde la decrépita anciana hasta la moza más joven. Sin embargo, la figura más llamativa -por su disposición, su gestualidad y su caracterizaciónes aquella que aparece fumando y que, inequívocamente, representa el perfil humano e iconográfico que, en muchas ocasiones, estereotipará a estas trabajadoras. No obstante, es de justicia reconocer que en la configuración de este cliché existe una fundamentación sobre algunos modelos reales. Uno de los rasgos más destacados en esta mujer, que ocupa activamente el espacio, con una actitud picaresca y socarrona, típica de muchas pescadoras, es su comportamiento, relacionado con los patrones propios de la identidad tradicional masculina.

En este sentido, advertimos en su concepción cierta caricaturización que aúna lo feo, lo cómico y lo obsceno y que, sin ser excesivamente explícita, define una fórmula que entrelaza caracterización masculina y estética de lo feo. A su vez, de alguna manera, este arquetipo iconográfico nos trae a la memoria aquella sanción simbólico-social frecuentemente aplicada a estas mujeres por ocupar un espacio ajeno al hogar y que, por tanto, no les corresponde (Marugán Pintos, 2012).

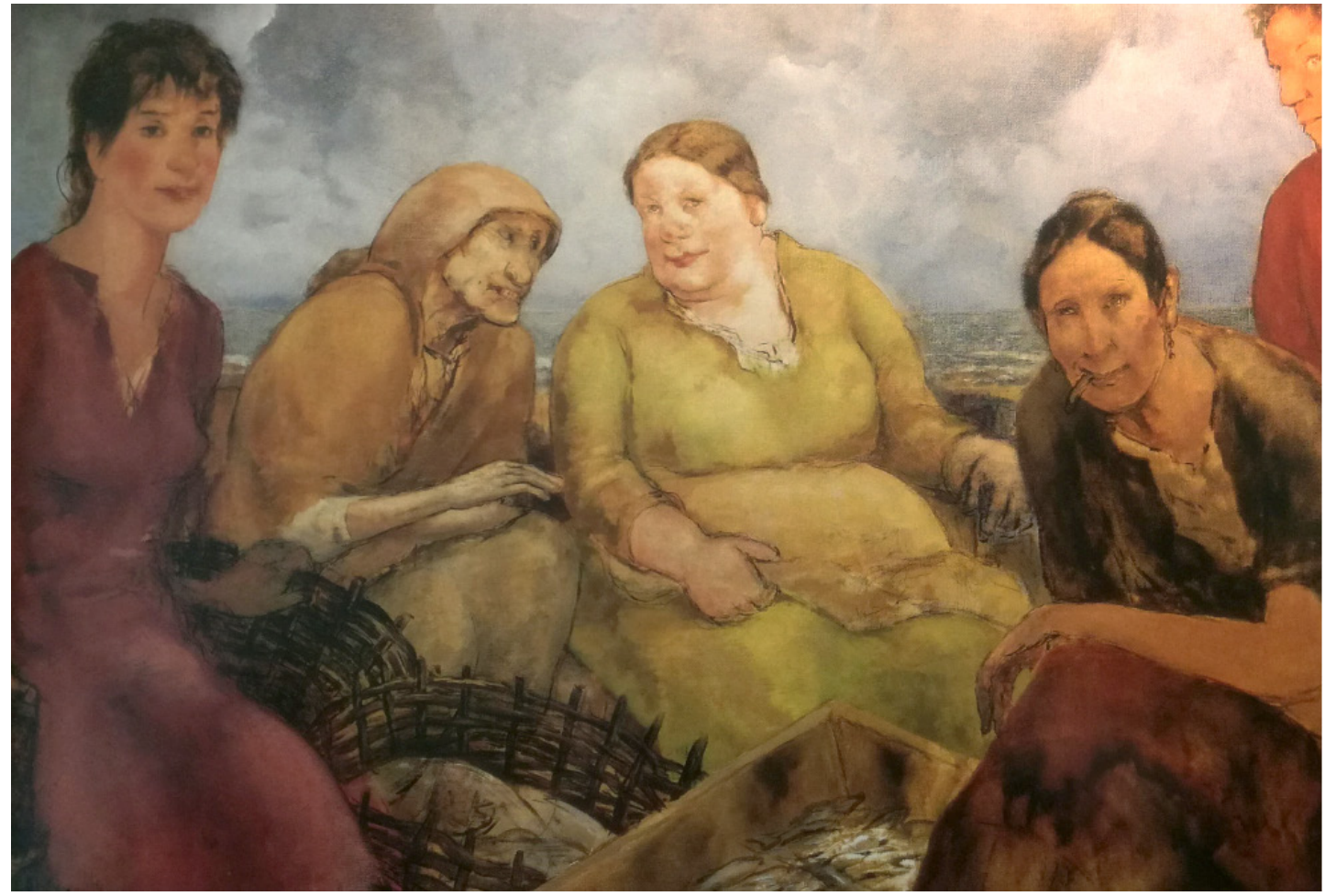

Figura 8. Pescaderas (ca. 1949) De Evaristo Valle. Colección del Museo de Bellas Artes de Asturias (Oviedo).

Sin embargo, su representación también responde al modo de expresión del artista y a la voluntad de captación psicológica. Al respecto, es de sobra conocido el sentido de supervivencia y el fuerte temperamento del que a veces hacían gala estas mujeres, así como el ingenio y la labia desplegados a la hora de llamar la atención de los compradores para vender en un contexto de fuerte competencia. Además, la obra nos resulta interesante porque, aunque la costumbre de fumar era frecuente entre las pescaderas, apenas aparece representada ${ }^{16}$.

También sabemos que algunos artistas recurrían a las pescaderas para ejecutar sus obras y retratos, caso de la Sardinera (ca. 1895) de Félix González-Nuevo, quien retrató a una pescadera de la zona para definir a su protagonista. No obstante, los rasgos de estas modelos solían ser empleados como punto de partida en la construcción de un retrato idealizado, así como base para otras caracterizaciones de tipo expresivo. Siguiendo esta línea, conocemos las identidades de algunas de estas mujeres, como La Pacha, personaje retratado por Juan Martínez

16 Gracias a la fotografía y a los registros documentados en otras fuentes, sabemos de esta costumbre en muchas pescadoras (sobre todo aquellas de mediana y avanzada edad). A tal efecto, contamos con fotografías como las de Ángela Pidal ("La Prina"), popular pescadera del barrio de Cimadevilla (Gijón). Para más información, consúltese la Fototeca del Museo del Pueblo de Asturias (Gijón). 
Abades en varias pinturas. Aunque con diferencias, como el escenario, la ambientación o la edad de la retratada, esta mujer aparece representada en diversos entornos portuarios de la localidad gijonesa. Asimismo, las fuentes disponibles nos ofrecen referencias, algunas de ellas en fechas cercanas al año de ejecución de uno los cuadros:

"Si ustedes, queridos lectores, fueran por la calle y les insultara La Pacha (...), ¿qué harían? ¿Discutir con tal percal? Pues por eso callo yo a ciertas cosas" (El Noroeste, 4 $-\mathrm{X}-1899)$.

A las apreciaciones conductuales, se le suman referencias de las multas percibidas y los problemas experimentados con la ley:

"En 25 pesetas fue multada una mujer conocida como La Pacha, la cual dirigió repetidos insultos a un guardia municipal y varios obreros empleados en obras que se derriban en la calle Corrida, blasfemando además en la vía pública. Todo porque (...) pretendía apoderarse de unos trozos de madera (...) había y los obreros no se lo permitieron” ( $E l$ Noroeste, 13-XII-1901).

Otro ejemplo:

"(Multa) De 10 pesetas a una individua apodada La Pacha, domiciliada en la calle del Rosario, que (...) insultó groseramente a un guardia municipal porque este fue a notificarla una multa" (El Noroeste, 31-X-1906).

\subsection{REPRESENTACIONES DEL TRABAJO INFANTIL}

En términos generales, la infancia de quienes vivían en entornos marineros solía ser corta, ya que a una edad temprana los niños eran instruidos en la navegación, la pesca o el amarre, mientras que a las niñas se les enseñaba a coser redes, o se las enviaba a las fábricas. En este sentido, el empleo de la mano de obra infantil en las labores de pesca y de transformación es de sobra conocido puesto que, en el caso de las conserveras, la demanda de trabajo era tal que sólo con mujeres no podía ser cubierta, por lo que las niñas eran también empleadas. Asimismo, éstas ayudaban en las labores de traslado de las sardinas o los bocartes desde los puertos, los muelles y las playas hasta las bodegas o las fábricas en las que los pescados habrían de prepararse.

Sabemos que este trabajo estaba remunerado y que, en cierta medida, se controlaba, puesto que a estas niñas se les entregaba una chapa que habrían de canjear por dinero una vez acabara su jornada. Al igual que las mujeres, las niñas que transportaban el pescado eran conocidas como carretadoras. Además, las empresas de procesado se aprovechaban de la abundancia de recursos a bajo precio, así como de la mano de obra femenina barata. Es por ello que las familias marineras, compuestas por hombres pescadores y mujeres salazoneras, empujaban a sus hijos a trabajar desde corta edad. Del mismo modo, la legislación existente era escasa y, a su vez, bastante laxa y permisiva, puesto que los niños y las niñas de siete y ocho años podían incorporarse al mercado laboral. No obstante, era más habitual encontrar niños de entre diez y catorce años en estos entornos (Muñoz Abeledo, 2012).

Aunque es difícil calcular las tasas reales de ocupación infantil, contamos con algunos estudios que establecen parámetros y referencias, arrojando luz sobre la realidad de este trabajo remunerado en la pesca y la industria conservera. Precisamente, estos estudios se centran en diversas fases cronológicas que, como tales, poseen sus propias características. Sin embargo, se dispone de materiales y fuentes en abundancia a partir de la mitad del siglo XIX, coincidiendo con el aumento en la demanda de estos productos por diversos motivos (mejora de los transportes y las comunicaciones, aumento de la demanda de productos en las ciudades, etc.) y, por tanto, el incremento de su manufactura (Muñoz Abeledo, 2014).

Conservamos diversas imágenes que nos muestran estos trabajos infantiles, aunque desde una doble vertiente que, en buena medida, queda condicionada por la cronología de 
la obra y, en consecuencia, por las condiciones socioeconómicas y el marco legal propio de cada época. No obstante, en términos generales, podemos señalar la presencia de escenas sobre la transmisión de los saberes y oficios, frecuentemente en el contexto de la formación y de la contribución a la economía doméstica, así como otras imágenes probablemente relacionadas con el trabajo remunerado. De todos modos, en muchas ocasiones resulta difícil discernir cuál de las dos situaciones está siendo representada. De este modo, lo que puede ser verdaderamente considerado es el valor de estas imágenes como muestra de la configuración y cristalización de las identidades laborales adultas, mediante un trabajo infantil ya segregado y especializado por sexo-género.

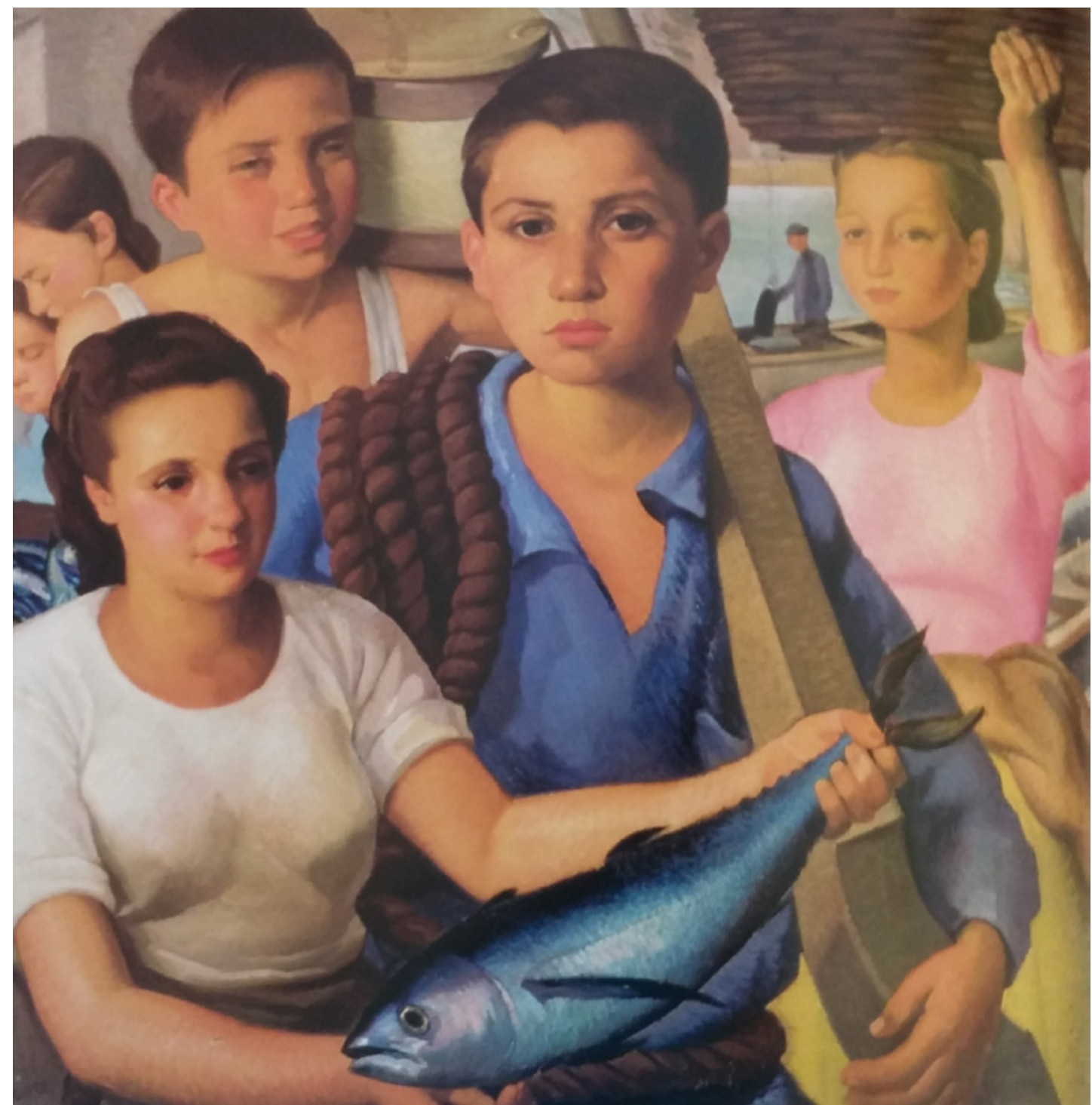

Figura 9. Los hijos del patrón (s.f.) de Mariano Moré. Colección familia de Mariano Moré (Gijón).

Esta situación se advierte en obras como Los hijos del Patrón (s.f.) de Mariano Moré, cuyos niños, hijos del patrón de un barco, aparecen ampliamente familiarizados con el mundo de la navegación y de la mar, portando una serie de objetos propios de esta cultura. Por ejemplo, el niño que parece llamado a heredar la profesión paterna porta elementos relacionados con la embarcación, como el timón o las cuerdas, dominando jerárquicamente la composición. De entre los demás personajes, de menores dimensiones, advertimos un cargador, una porteadora y una vendedora de pescado. A tal efecto, sabemos que era habitual encontrar en los puertos estos perfiles profesionales, así como recaderos y boteros, tratándose estos últimos de niños que rozaban los doce años de edad, al tener que disponer de fuerza suficiente para sacar los botes de remo. Así, estos eran empleados para hacer de puente o enlace entre el muelle y las embarcaciones de gran calado que, por sus dimensiones o por la congestión espacial, no podían 
atracar. Asimismo, era frecuente ver a estos niños amarrando las embarcaciones que entraban en el puerto, tarea que podían desempeñar gracias al conocimiento adquirido en materia de nudos.

Otra obra que nos muestra el trabajo infantil, en esta ocasión desde una ambientación familiar e informal, es Marineros en el puerto (ca. 1943) de Andrés Vidau, donde un pescador y una niña reparan las redes, quizás instruyendo el primero a la segunda. Como se ha venido advirtiendo a lo largo de este trabajo, muchas de las labores femeninas contaban con la ayuda de los niños, tal y como se exponía en las tareas de marisqueo y de recogida del ocle. En esta línea, contamos con algunas fotografías, como las de Constantino Suárez, de gran valor documental.

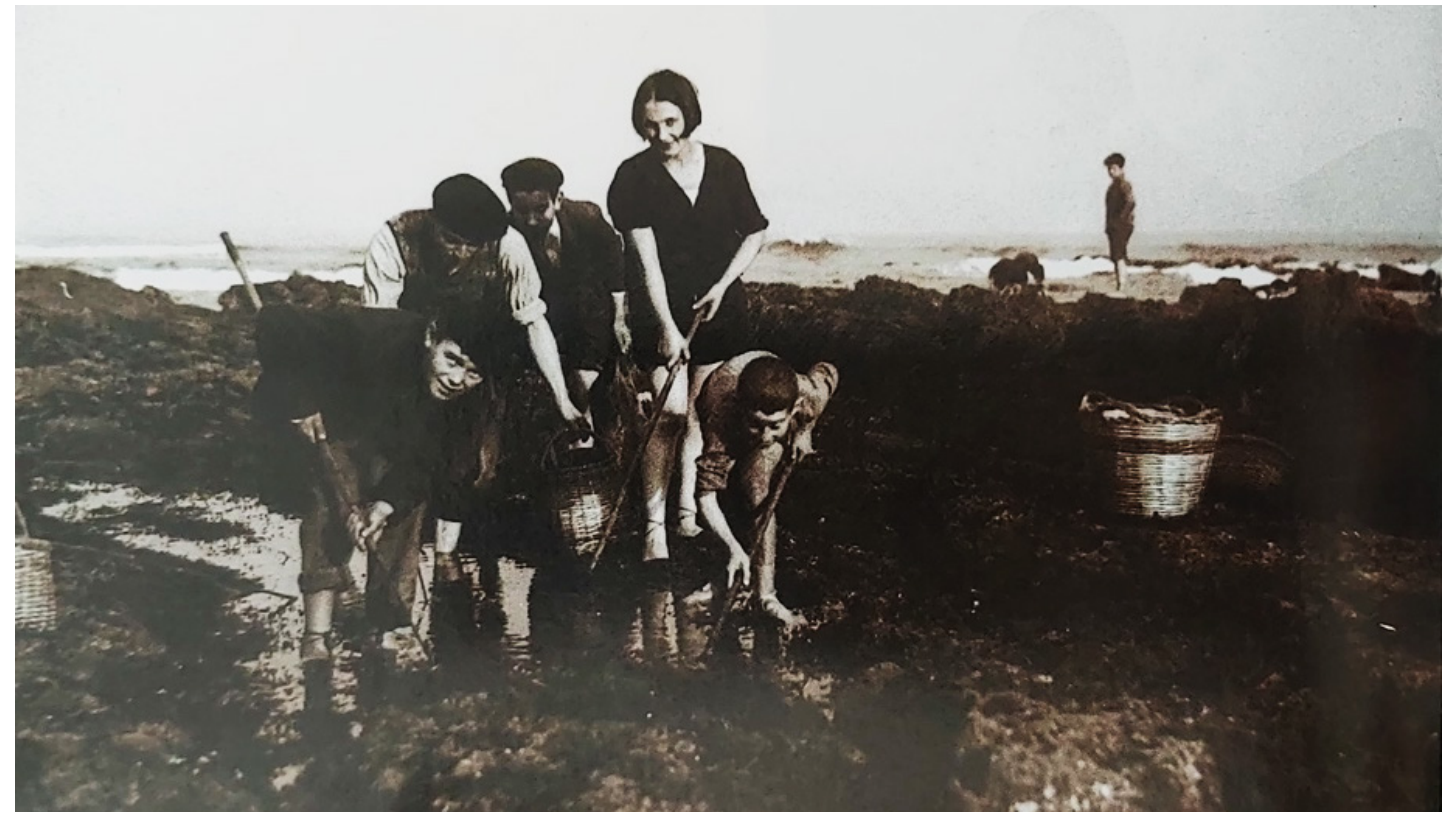

Figura 10. Fotografía del “Archivo Constantino Suárez (1920-1977)”, Archivo Municipal de Gijón.

\section{CONCLUSIONES}

Las imágenes de los trabajos y oficios asociados al mar se ajustan, en buena medida, a la situación socioeconómica, al momento histórico y a las características propias de la realidad en la que han sido creadas. A tal efecto, encontramos una fuerte segregación y especialización del trabajo por sexo-género, tal y cómo se ha venido comentando. Las mujeres aparecen frecuentemente vinculadas a las playas y a los pedreros, cercanos a la vivienda, haciendo las veces de mariscadoras, acopiando moluscos o crustáceos, pero también el ocle, aquella alga tan apreciada para el abono de la tierra. Además de la presencia habitual de espacios masculinos y femeninos, advertíamos algunos espacios mixtos, como el puerto o la rula, lugar en el que hombres y mujeres colocaban, vendían y compraban. No obstante, también se comprobaba la escasa representación de algunos trabajos femeninos, frente a la presencia hegemónica de casi todos los quehaceres masculinos. Tal es el caso del trabajo de las rederas y las conserveras para el conjunto de la obra estudiada.

Igualmente, hemos podido distinguir cómo las esperas, bien se esté aguardando a la bajamar para comenzar a faenar, bien intentando divisar la vuelta de los seres queridos, forman parte del imaginario femenino habitual. Si bien estas últimas no pueden ser clasificadas en el ámbito de los trabajos y oficios, se traen a la memoria ya que nos permiten completar y enriquecer esta lectura comparada, otorgándole un sentido específico al imaginario.

También disponemos de representaciones que recogen otras tareas fundamentales como son las de distribución, porteo, venta y reventa del pescado. A pesar de la idealización mencionada, muchas de las imágenes se mueven entre el género costumbrista y aquel otro que se acerca a la temática social. Al respecto, el lenguaje figurativo y estilo convencional que muestran estas obras ha facilitado sobremanera la identificación y la localización de las escenas y las labores. Sin embargo, aun con la fidelidad con la que cuentan, seguimos percibiendo en estas representaciones cierta desdramatización de las condiciones de vida y de trabajo de estas comunidades. 


\section{BIBLIOGRAFÍA}

- Broullón Acuña, E. (2011). La política sexual y la segregación ocupacional en las sociedades pesqueras. En Revista Estudos Feministas, 19 (1), 73-89.

- Díaz Quirós, G. (2002). Ventura Álvarez Sala. En Enciclopedia de Artistas Asturianos. Oviedo: Hércules Astur, t. I, 496-531.

- Díaz Quirós, G. (2006). Asturias para el recuerdo. El campo, la mar, la industria. Oviedo: Hércules Astur.

- Fandos Rodríguez, L. (2000). La mujer trabajadora en Gozón (1750-1960). Luanco: Museo Marítimo de Asturias.

- Fandos Rodríguez, L. (2006). La costa y el mar de Asturias. En Asturias y la Mar. Oviedo: Editorial Prensa Asturiana y Ediciones Nobel, 655-680.

- García Martínez, A. (2008). Antropología de Asturias. Oviedo: KRK ediciones.

- Junquera Huergo, J. (1991). Gramática asturiana. Oviedo: Academia de la Llingua Asturiana.

- Machicado Compañy, M. (1988), Terminoloxía marinera de Cimavilla. En Lletres asturianes. Boletín Oficial de l'Academia de la Llingua Asturiana, 28, 101-108.

- Macías Muñoz, M.O. (2016). Las mujeres y las actividades marítimas en el País Vasco. Trabajo portuario y ámbito pesquero (1700-1950). En Itsas memoria. Revista de estudios maritimos del País Vasco, n. 8, 831-845.

- Martínez García, P. (2017). Democratizando el mar con perspectiva de género. El proceso de profesionalización de las mariscadoras a pie en Galicia. En Política y Sociedad. Madrid: Ediciones Complutense, n. 54 (2), 377-398.

- Marugán Pintos, B. (2012). La organización de las mariscadoras como agentes de transformación social, En Debate, 7, 82-106. Disponible en: http://dx.doi.org/10.5007/19803532.2012n7p82 [Última consulta: 13-IV-2021, 11:21].

- Mier Valerón, L. (2017). Iconografías portuarias. Miradas artísticas del litoral asturiano. Oviedo: Universidad de Oviedo. Tesis doctoral inédita.

- Muñoz Abeledo, L. (2012) Actividad femenina en industrias pesqueras de España y Portugal (1870-1930). En Historia Contemporánea, n. 44, 49-72.

- Muñoz Abeledo, L. (2014). El trabajo infantil en la pesca e industrias de transformación de pescado en España, 1850-1936. En Documentos de Trabajo (AEHE), n. 1407, 1-39.

- Ocampo Suárez-Valdés, J. (1999). Las conservas de pescado en Asturias, 1880-1930. En Actas del $V$ Congreso de Historia Económica. Zaragoza: Universidad de Zaragoza.

- Ocampo Suárez-Valdés, J. (2002). Cambio técnico e industrialización pesquera en Asturias (1880-1930). En Historia agraria. Revista de agricultura e historia rural, n. 28, 69-90.

- Pérez de Castro, J. L. (1963), Los abonos naturales en la agricultura asturiana: el folklore astur en las algas fertilizantes, en Actas do $1^{\circ}$ Congresso de Etnografia e Folklore, 215-225.

- Rodríguez Rodríguez, M. R. (2006a), La industria pesquera y conservera en Gijón (19002005). En Puerto de Gijón. Pesca y conserva, Oviedo: Ediciones Nobel, 68-119.

- Rodríguez Rodríguez, M. R. (2006b). Las artes de la pesca. En Asturias y la mar. Oviedo: Editorial Prensa Asturiana y Ediciones Nobel, 182-202.

- Rodríguez Rodríguez, M.R. (2006c). Oficios auxiliares de la pesca. En Asturias y la mar. Oviedo: Editorial Prensa Asturiana y Ediciones Nobel, 321-340.

- Rodríguez Rodríguez, M. R. y Crabiffosse Cuesta, F. (1990). Las conservas de pescado en Asturias. Candás: Ayuntamiento de Carreño.

- Rodríguez Rodríguez, M.R. y López de Prado Nistal, C. (2021). Iconografía femenina en la industria conservera de pescado en Asturias (1893-1986). Gijón: Museo Nicanor Piñole.

- Vigón, B. (1980). Asturias. Folclore de Mar. Juegos infantiles. Poesía popular y otros estudios. Oviedo: Biblioteca Popular Asturiana. 